\title{
Vulnerabilidade externa e controle de capitais no Brasil: \\ uma análise das inter-relações entre câmbio, fluxos de capitais, IOF, juros e risco-país
}

Vanessa da Costa Val Munhoz Professora do IE/UFU

\section{Palauras-chave \\ vulnerabilidade externa, controle de capitais, IOF}

Classificação JEL E44, F31, F32, F36

\section{Key Words}

External Vulnerability, Capital Controls, IOF

JEL Classification E44, F31, F32, F36

\section{Resumo}

Diante da severidade da crise financeira internacional de 2007/08, a vulnerabilidade externa de países em desenvolvimento se manifestou mais fortemente, trazendo à baila a rediscussão do controle de capitais. À luz da importância da restrição ao livre fluxo internacional de capitais, o objetivo deste trabalho é investigar a inter-relação entre as seguintes variáveis da economia brasileira: câmbio, fluxos de capitais, IOF, juros e risco-país. Especificamente, pretende-se verificar se uma cobrança mais alta do IOF gera impactos relevantes sobre os fluxos financeiros mais voláteis no período 1995-2011. Por meio da aplicação do modelo VAR, a análise empírica sugere que os capitais especulativos respondem pouco a pequenas alteraçóes de alíquotas desse imposto, estando mais intimamente associados a movimentos da taxa de câmbio e do risco-país. Em virtude da pouca eficácia do controle de capitais via IOF, destaca-se, assim, a necessidade de medidas mais concretas, que inibam efetivamente a especulação dos investidores estrangeiros.

\section{Abstract}

In face of the severity of the financial crisis of 2007/08, the external vulnerability of developing countries has increased. This has brought up the reassessment of capital controls. Based on the importance of restricting international capital movements, the aim of this paper is to investigate the interrelation between the following variables of the Brazilian economy: the exchange rate, capital flows, the IOF (Tax on Financial Operations), interest rates and country risk. Specifically, we intend to assess whether a higher IOF on foreign exchange transactions leads to significant impacts on volatile capital flows between 1995 and 2011. By applying a VAR model, the empirical analysis suggests that speculative financial flows respond poorly to small changes in the IOF. They are more closely associated with movements in the exchange rate and in the country risk. Given the low efficacy of capital controls via the IOF, we stress the need for more concrete measures that effectively inhibit foreign investors' speculation. 


\section{1_Introdução: vulnerabilidade externa brasileira e o uso de controle de capitais}

Diante da severidade da crise financeira internacional de 2007/2008 e de suas extensóes, a vulnerabilidade externa de países que dependem do ciclo de liquidez internacional para o equilíbrio do balanço de pagamentos e da taxa de câmbio voltou à tona nas discussóes acadêmicas e políticas nacionais e internacionais. Para autores mainstream, choques externos inesperados podem ser corrigidos valendo-se da "boa gestão" macroeconômica, com base na utilização de instrumentos convencionais de política econômica, sobretudo via manejo das taxas de juros. Todavia, o que se quer apontar no presente trabalho é que a vulnerabilidade externa em países periféricos, como o Brasil, é explicada pela possibilidade de reversão súbita dos fluxos de capitais estrangeiros, que decorre de fatores puramente exógenos. Sendo assim, a dimensão dessa vulnerabilidade estaria "camuflada" por uma melhora de indicadores de endividamento externo que o país vem apresentando nos últimos anos graças ao aumento da capacidade de solvência externa (capacidade de pagamento dos compromissos financeiros externos) e da robustez dessa economia.

Nesse sentido, a diminuição do potencial de vulnerabilidade externa da eco- nomia brasileira envolve a redução da livre mobilidade de capitais. Isto é, faz-se necessária uma diminuição do peso da dimensão financeira na inserção externa do Brasil, e não se deve apenas aumentar a capacidade de acumulação de reservas internacionais, de forma a obter a consequente melhora de indicadores de dívida, mas que deixam o país sujeito à súbita reversão intensa dos fluxos de capitais.

No que diz respeito ao elevado peso de capitais financeiros no balanço de pagamentos do Brasil e seus impactos sobre a taxa de câmbio, o apontamento mais frequente no debate econômico atual para sua diminuição é que o país deve continuar utilizando medidas de controles de capitais. Não só o FMI já os aceita e os recomenda, ${ }^{1}$ ainda que com algumas restrições, como já foram divulgados ma-

\begin{tabular}{|c|c|}
\hline $\begin{array}{l}{ }^{1} \text { Para Ostry et al. (2010) - } \\
\text { economistas e pesquisadores } \\
\text { do FMI - as massivas ondas } \\
\text { de influxos de capitais } \\
\text { podem gerar complicaçóes } \\
\text { para o gerenciamento } \\
\text { macroeconômico, assim } \\
\text { como criam riscos financeiros. } \\
\text { Outro exemplo de que a } \\
\text { discussáo dos controles de } \\
\text { capitais está circundando } \\
\text { o ambiente econômico é a } \\
\text { advertência publicada no }\end{array}$ & $\begin{array}{l}\text { Global Financial Stability } \\
\text { Report, April 2010, do } \\
\text { FMI, de que países em } \\
\text { desenvolvimento devem seguir } \\
\text { o exemplo do Brasil, que } \\
\text { adotou controles de capitais } \\
\text { diante da crise financeira } \\
\text { global de } 2007 / 2008 \text {. }\end{array}$ \\
\hline
\end{tabular}


nifestos ${ }^{2}$ de economistas de vários países defendendo os controles. Assim, não só os economistas, mas também os policymakers têm sido favoráveis aos controles de capitais, especialmente aqueles que incidem sobre os seus influxos, capazes de limitar a sobrevalorização cambial e reduzir a fragilidade financeira resultante dos fluxos de capitais voláteis (Forbes et al., 2011). No início do ano passado, foi publicado um relatório ${ }^{3}$ do FMI endossando a proposta, conforme objetivo explicitado a seguir:

This paper reviews the recent experience of Emerging Markets (Ems) in dealing with capital inflows and suggests a possible framework for IMF policy advice on the spectrum of measures available to policymakers to manage inflows, including macroeconomic policies, prudential measures and capital controls (International Monetary Fund, 2011, p. 3).
Essas discussōes sempre englobam o Brasil como um país que adota controle sobre a entrada de capitais via cobrança de um imposto. Defende-se que o Imposto sobre Operaçóes Financeiras (IOF) limita a entrada de capitais estrangeiros e pode ser utilizado como medida para prevenção de crises financeiras. No entanto, mesmo com a introdução de alíquotas mais elevadas do IOF sobre os fluxos de capitais para aplicação no mercado financeiro e de capitais do Brasil, ${ }^{4}$ a volatilidade dos fluxos financeiros permanece inexoravelmente alta. Se há possibilidade de reversão dos recursos financeiros a qualquer momento, o potencial de vulnerabilidade externa se mantém. De outra maneira, a interpretação que aqui se coloca é a de uma dimensão mais ampla da vulnerabilidade externa brasileira, que se refere à capacidade de proteção contra choques externos, envolvendo instru-
${ }^{2}$ Em 1\%/2/2011, o site "Carta Maior" publicou um manifesto, com o título "We recommend to deploy Capital Controls", de um grupo de economistas dos Estados Unidos e de outros países enviado à secretária de Estado, Hillary Clinton, e ao secretário do Tesouro dos EUA, Timothy Geithner, defendendo a adoção de mecanismos de controle de capitais especulativos como instrumento para enfrentar a crise financeira global. Para a íntegra do manifesto, ver: <http:// cartamaior.com.br/templates/ materiaMostrar.cfm?materia id $=17355 \&$ alterar

HomeAtual=1.>. Acesso em: 23 de junho de 2011.

\author{
${ }^{3}$ Disponível em: <http:// \\ www.imf.org/external/np/pp/ \\ eng/2011/021411a.pdf>. Acesso \\ em: 21 de junho de 2011. \\ ${ }^{4} \mathrm{Na}$ seção 3 deste trabalho \\ e no Anexo A, a legislaçáo \\ vigente do IOF será detalhada, \\ bem como será apresentado \\ um histórico das suas alíquotas.
}


mentos de política econômica utilizados pela autoridade doméstica e os custos de enfrentamento dos choques, especificamente aqueles que impactam o arranjo macroeconômico.

Com base nessa ideia de vulnerabilidade e considerando a importância do uso de medidas para conter o livre fluxo internacional de capitais, o objetivo deste trabalho é investigar a inter-relação entre as seguintes variáveis: câmbio, fluxos de capitais, IOF, juros e risco-país. Especificamente, pretende-se verificar se uma cobrança mais alta do IOF sobre operaçóes cambiais gera impactos relevantes sobre os fluxos de capitais mais voláteis do balanço de pagamentos brasileiro. A hipótese sustentada por este trabalho é que os fluxos financeiros estão fortemente associados a variáveis que representam a lógica da rentabilidade dos investidores, o que gera forte especulação e impactos sobre a taxa de câmbio. Não obstante, acredita-se, sim, que os investidores estrangeiros modifiquem suas alocações de portfólio perante taxas mais altas. Essas alocaçóes, porém, continuam sendo frequentemente alteradas, de forma que a volatilidade dos fluxos de capitais direcionados ao Brasil permanece. Dito de outra maneira, acredita-se que alteraçóes do IOF talvez gerem apenas efeitos no âmbito microeconômico, ao afetarem as alo- cações de portfólio, não produzindo, assim, impactos sobre o volume dos fluxos totais de capitais e sobre os capitais com viés de curto prazo.

Se essa hipótese for empiricamente corroborada, indicaremos um posicionamento favorável à adoção de controles mais abrangentes de capitais na economia brasileira. Ademais, aponta-se a necessidade de reflexão sobre um conjunto de medidas alternativas mais adequadas para a diminuição da especulação que assola as contas financeiras brasileiras.

Se a literatura nacional e internacional ainda não atingiu uma conclusão acerca de uma medida adequada para a análise da eficácia dos controles de capitais, acreditamos que evidências empíricas que mostrem que a ampla liberdade dos fluxos de capitais gera impactos negativos, sobretudo para economias em desenvolvimento, são suficientes para justificarem controles abrangentes, que não apenas inibam a entrada de capitais especulativos em certos momentos, mas que limitem quantitativamente o forte influxo.

$\mathrm{O}$ artigo está dividido em mais três seções, além desta introdução. Após uma apresentação de justificativas apontadas pela literatura para o seu uso, e dos tipos existentes de controles de capitais (seção 2), será feita uma análise da medida que vem sendo adotada pelo Brasil para con- 
trolar os fluxos financeiros: a taxação via IOF (seção 3). Em detalhes, apresentar-se-á uma caracterização desse imposto, bem como um histórico de suas alíquotas. Em seguida (seção 4), será realizada a análise empírica da inter-relação proposta, por meio da metodologia de Vetores Autorregressivos (Modelo VAR irrestrito). Por fim, à guisa de conclusão, serão tecidas algumas considerações finais (seção 5).

\section{2_Controles de capitais: justificativas e tipos de medida}

Em virtude das divergências teóricas acerca do debate sobre os controles de capitais, cabe inicialmente apontar de forma breve a visão mainstream sobre essa temática ou, mais especificamente, a visão contra a utilização de controle de capitais. $\mathrm{O}$ argumento mais geral dentro desse matiz teórico é o de que a liberalização financeira traz benefícios às economias, uma vez que os mercados financeiros tendem a alocar os recursos de forma mais eficiente quando não há obstáculos à livre movimentação de capitais entre fronteiras. Para o mainstream economics, a abertura financeira permite o aumento da eficiência na alocação dos fatores, a absorção de poupança externa, a dinamização da intermediação financeira externa e a diversificação dos riscos (Prates,
1997). Assim, a liberalização financeira, através de canais diretos e indiretos, seria benéfica para o sistema financeiro, de forma a gerar impactos no crescimento econômico e na distribuição de renda. Em última instância, a ideia embutida nessa visão teórica é a de que a eficiência dos mercados se deve à simetria de informações. Em temos específicos, há ainda outra ordem de argumento tipicamente mainstream, que trata a eficácia dos controles. Sobre essa questáo subjacente aos argumentos favoráveis à liberalização dos movimentos de capitais, Carvalho $\&$ Sicsú (2004, p. 169) apontam que: "Alega-se que controles de capitais são, no mais das vezes, inócuos, implicando desperdício de energias e de recursos em atividades fadadas ao fracasso".

Enquanto isso, a justificativa para utilização dos controles de capitais, base teórica para análise empírica a ser desenvolvida, parte do apontamento de que os livres fluxos internacionais de capitais tendem a ser pró-cíclicos, criando excesso de influxos durante booms e causando fuga de capitais em momentos de instabilidade, o que agrava as crises financeiras. Desta maneira, aponta-se que fortes influxos podem gerar reversóes abruptas de investidores estrangeiros. Isso ocorre porque os movimentos dos capitais internacionais são afetados pela política eco- 
nômica dos países que têm moeda forte, gerando ciclos reflexos nos países em desenvolvimento, que não emitem tal moeda. Assim, os movimentos de retração/ aumento das taxas de juros dos países centrais provocam expansão/fuga sobre os fluxos vinculados a países periféricos.

Há vasta literatura que trata as discussóes sobre os impactos negativos de uma conta de capitais operando livremente entre fronteiras, mesmo entre os mais diversos matizes teóricos. Embora o viés pró-liberalização permaneça, até o FMI e autores tipicamente do campo ortodoxo passaram a "flertar", mesmo que indiretamente e parcialmente, com controles de capitais do tipo chileno (sobre a entrada de capitais). $\mathrm{Na}$ verdade, o fundo admite genericamente que controles, limitados e temporários, merecem mais estudos.

Controles ou a administração sobre intensos fluxos de capitais podem ser desejosos com o intuito de evitar-se a reversão de fluxos financeiros - o famoso sudden stop, entre outros motivos a seguir detalhados. Para Forbes (2007a, 2007b), controles de capitais poderiam reduzir potencialmente os custos do livre movimento de capitais, como a apreciação da moeda doméstica, a reduçáo da competitividade das exportaçóes, a doença holandesa e a ineficiência dos investimentos devido a distorções do mercado.
Magud \& Reinhart (2006) registram as seguintes possíveis habilidades referentes à eficácia de controles de capitais:

1_ limita influxos de capitais;

2_ muda a composição dos fluxos (especialmente, pelo direcionamento rumo a passivos de longo prazo);

3_ aliviam pressóes da taxa de câmbio real; e

4_ geram maior independência para política monetária através $\mathrm{da}$ junção entre as taxas de juros doméstica e internacional.

Nesse sentido, controles de capitais são impostos com base em quatro medos: de apreciação, dos capitais de curto prazo, de grandes influxos e da perda de autonomia de política monetária (fear of appreciation, fear of hot-money, fear of large-inflows, fear of loss of monetary autonomy). ${ }^{5}$

Grabel (2003a, 2003b) associa fluxos internacionais de capitais privados (IPCFs) a cinco riscos: risco monetário, de fuga de capitais, de fragilidade financeira, risco de contágio e risco de soberania. Desse modo, a autora argumenta:

"Regulation of IPCFs is a central component of what can be thought of as a'developmentalist financial architecture', by which I mean a financial
${ }^{5}$ Ocampo \& Palma (2008) adicionam um quinto medo para justificar os controles de capitais: o medo de bolha de ativos. 
system that promotes equitable,

stable and sustainable economic

development" (Grabel, 2003a, p. 342).

Outros argumentos, ainda apontados pelos defensores de medidas de restrição aos fluxos de capitais, sugerem a possibilidade de tributação dos rendimentos de capital, viabilizando a adoção de política tributária distributiva - ao impedir que agentes domésticos transfiram recursos para países com menor tributação; e a possibilidade de serem utilizadas como instrumentos de política industrial para moldar a estrutura da oferta doméstica - ao incentivar a entrada de investimento direto externo para setores específicos.

Epstein, Grabel \& Jomo (2005) propóem técnicas de administração de capitais (capital management techniques doravante CMTs), referindo-se a dois tipos de política financeira complementares: políticas que governam os fluxos internacionais de capitais privados, os chamados "controles de capitais", e aquelas que executam gerenciamento prudente das instituiçóes financeiras domésticas. Com base nelas, os autores sugerem sete liçóes, listadas a seguir:

I_ CMTs podem contribuir para a estabilidade financeira e monetária, autonomia de políticas macro e microeconômicas, investimento de longo prazo estável e sólida performance da conta-corrente;

II_a implementação bem-sucedida de controles sobre um período significante de tempo depende da presença de um ambiente político sólido e fortes fundamentos (dívida pública/ PIB relativamente baixa, taxas de inflação moderadas, balanços fiscal e da conta-corrente sustentáveis, políticas de taxas de câmbio consistentes);

III_ há sinergia entre CMTs e fundamentos econômicos;

IV_é desejável administração de capital ágil e flexível;

V_ CMTs funcionam melhor quando são coerentes e consistentes com propósitos globais do regime de política econômica ou mesmo melhor, quando são parte integral de uma visão econômica nacional;

VI_ regulaçóes prudentes são, geralmente, um importante complemento para controles de capital e vice-versa; e

VII_ não existe um tipo de CMT que funcione melhor para todos os países, já que há variedade de estratégias. 
Não obstante seja fácil encontrar argumentos favoráveis e efeitos positivos de controles de capitais em economias em desenvolvimento, podemos apontar que os resultados sobre a análise dos impactos de controles de capitais são ainda inconclusivos. No que tange às evidências empíricas acerca desses controles, Carvalho \& Sicsú (2004) apontam algumas dificuldades, como a ausência de uma medida aceita do grau de controle efetivamente praticado em cada economia, a multiplicidade de objetivos dos controles e a dificuldade de escolha da variável relevante para medir a eficácia dos controles. Outra questáo levantada recentemente é a de que há pouca preocupação com os efeitos de spillovers dos controles sobre os fluxos de capitais para direcionados os outros países (Forbes et al., 2011).

Apesar da precariedade da base de dados em que os estudos empíricos sobre a relação liberalização/crescimento se apoiam, as evidências empíricas são muito menos favoráveis à remoção de controles. Ou seja, não há evidências que comprovem que os custos da redução da mobilidade de capitais superam os benefícios. Muitas objeções a esse tipo de política são guiadas por preconceitos, dominados por elevada carga ideológica (Oreiro, 2006).

No que toca às definiçóes, tipos e instrumentos de controles de capitais, es- ses podem assumir diferentes formas e são geralmente definidos como restrições aos movimentos de capitais entre as fronteiras de um país, podendo agir sobre os capitais estrangeiros que entram ou que saem do país. Não obstante, dados os híbridos formatos, tipos e instrumentos de controle, a temática sobre como definir a restrição dos fluxos internacionais de capitais, sobretudo os capitais especulativos, gera controvérsias.

Seguindo os propósitos deste trabalho, melhor definição de controle de capitais seria colocada a partir de medidas efetivas, no sentido de serem abrangentes e intensas sobre a restrição dos fluxos de capitais. Assim, consideramos ainda que os controles devem ser baseados em instrumentos exógenos (antes da explosão de uma crise financeira). Para nós, a proposta de controle de capitais deve se situar na adoção de controles permanentes (de capitais), limitando efetivamente a entrada de fluxos particularmente especulativos.

Tendo clara uma definição própria de controles de capitais, mostramos também diferentes classificaçóes e tipos de medida. No que tange ao grau de permanência, os controles podem ser temporários ou permanentes. Podem ser adotados instrumentos de mercado, os controles indiretos ou precificados; ou controles 
${ }^{6}$ Está disponível no Anexo A um quadro resumo com as principais medidas dispostas sobre o IOF. diretos, chamados de "controles administrativos". Podem também ser classificados quando ao tipo de movimento que se deseja controlar, sendo assim classificados em controle sobre a saída de capitais ou em controle sobre a entrada de capitais. Quanto à abrangência, eles podem ser seletivos ou extensivos (sobre diversos tipos de fluxo e diferentes atores). Podemos classificá-los ainda quanto à circunstância da adoção, isto é, se são adotados sob contexto de crises (controles endógenos) ou se são extensivos (controles exógenos). Por fim, há diferenças no que diz respeito aos seus efeitos, uma vez que os controles podem ser impostos, mas não apresentarem efetividade, representando apenas uma sinalização ao mercado financeiro de capitais.

\section{3_Controle de capitais no Brasil via Imposto sobre Operações Financeiras (IOF) ${ }^{6}$}

Segundo vários autores (Cardoso \& Goldfajn, 1997; Soihet, 2002; Paula, Oreiro e Silva, 2003; Silva \& Resende, 2010), os controles de capitais no Brasil são endógenos às condiçóes de financiamento externo. Em outras palavras, defende-se a hipótese de que os próprios movimentos dos fluxos de capitais influenciam a legis- lação que trata do assunto; isto é, as autoridades monetárias reagem aos efeitos dos fluxos de capitais criando outros controles. Nesse sentido, quando da ocorrência de grandes influxos, as autoridades tendem a impor controles a fim de evitar as mazelas criadas com o excesso de liquidez, tais como a apreciação da taxa de câmbio. Em suma, controles seriam impostos sobre a entrada nos momentos de extrema liquidez internacional com o intuito de restringir o ingresso no país; e impostos sobre a saída, em momentos de escassez monetária internacional, em que os controles seriam afrouxados com o objetivo de aumentar o ingresso de capitais.

No mesmo passo, estudos recentes da literatura econômica internacional, ao tratar dos instrumentos utilizados no Brasil a fim de restringir a liberdade dos fluxos de capitais, apontam que esses são aplicados sobre a entrada de capitais externos e viabilizados pela cobrança do imposto sobre operaçóes financeiras (IOF) (IMF, 2011; Forbes et al., 2011). Ao abordar o tema, Terra e Soihet (2006) corroboram com a escolha do IOF como principal instrumento utilizado para controlar capitais no Brasil, ao exemplificar uma medida restritiva usando um provável aumento de sua alíquota sobre fundos de renda fixa. As autoras supracitadas reiteram o argumento ao citar a Portaria do 
Ministério da Fazenda (MF) $\mathrm{n}^{\circ} 202$ de 10/08/1995, medida para aumentar o IOF sobre a captação de recursos estrangeiros, a fim de evitar maiores apreciaçóes cambiais.

Sobre o uso do IOF como controles de capitais, Silva \& Resende (2010, p. 2) também afirmam que:

As evidências de controles de capitais adotados no Brasil na década de 1990 sugerem que estes eram endógenos, aplicados sobre a entrada de recursos estrangeiros e feitos por intermédio da cobrança de Imposto sobre Operaçôes Financeiras (IOF). Os controles eram feitos sobre a entrada de capitais externos. O governo reagia aumentando o controle nos periodos de boom e liberalizando nos periodos de crise.

Carvalho \& Garcia (2006) também mostram que a cobrança do IOF foi uma das principais medidas para controlar influxos de capitais na década de 1990, embora o mercado tenha manejado "dribles" contra o IOF de inúmeras maneiras e obtido ganhos com as taxas de juros elevadas sem pagar o imposto. Assim, tendo por base os trabalhos citados, a presente análise objetiva examinar o Imposto sobre Operaçóes Financeiras (IOF), como principal instrumento utilizado no país para tentar controlar os fluxos de capitais estrangeiros. $\mathrm{O}$ intuito é verificar co- mo essa medida tem impactado sobre a dinâmica dos fluxos de capitais, para, enfim, gerar uma argumentação mais concisa no que tange a uma medida possivelmente mais adequada para controlar fluxos especulativos de capitais.

No que diz respeito à caracterização do imposto, temos que o IOF - Imposto sobre Operações de Crédito, Câmbio e Seguros, ou relativas a Títulos e Valores Mobiliários - foi instituído tal como é hoje a partir da Lei $\mathrm{n}^{\circ} 8.894$, de 21 de junho de 1994 . O art. $5^{\circ}$ da referida lei é importante para este trabalho na medida em que regula a incidência do IOF sobre operações de câmbio, estabelecendo a alíquota de $25 \%$ sobre o valor da liquidação das operaçóes. Ainda, o art. $5^{\circ}$ explicita o caráter de instrumento de política monetária atribuído ao IOF, ao deixar claro que as alíquotas poderão ser alteradas de acordo com os objetivos de política econômica do governo. A preocupação especial com tal artigo se justifica exatamente por ele tratar da incidência do IOF sobre operaçóes cambiais, instrumento esse consagrado pela literatura como principal medida para controlar os fluxos de capitais no Brasil.

De acordo com o Decreto n ${ }^{\circ} 2.219$, de 2 de maio de 1997, que regulamenta o IOF, o fato gerador sobre operaçóes de câmbio é a entrega de moeda nacional 
ou estrangeira, ou de documento que a represente, ou sua colocação à disposição do interessado, em montante equivalente à moeda estrangeira ou nacional entregue ou posta à disposição por esse. Conforme apontado em Silva \& Resende (2010), configuram-se como hipóteses para a incidência do IOF na entrada de recursos as seguintes operaçóes:

I_ Operaçóes de câmbio relativas aos ingressos de receitas de exportações de bens e serviços;

II_Operaçôes de câmbio de transferências do exterior, relativas às aplicações em fundos de investimento;

III_Operaçóes de compra de moeda estrangeira por instituição autorizada a operar no mercado de câmbio;

IV_Operações de câmbio relativas a transferências do exterior, inclusive por meio de operaçóes simultâneas, realizadas por investidor estrangeiro, para aplicação nos mercados financeiros e de capitais, etc.

Sobre a saída de capital, o IOF pode incidir sobre as seguintes operaçóes:

I_operaçôes de câmbio destinadas ao pagamento de importação de serviços;
II_operaçóes de câmbio destinadas ao cumprimento de obrigações de administradoras de cartão de crédito ou de bancos comerciais ou múltiplos na qualidade de emissores de cartão de crédito decorrentes de aquisição de bens e serviços do exterior, por seus usuários;

III_operações de câmbio de transferências para o exterior, relativas as aplicações em fundos de investimento;

IV_pagamento de bens importados;

V_operaçóes de câmbio relativas a transferências para o exterior, inclusive por meio de operaçóes simultâneas, realizadas por investidor estrangeiro, para aplicação nos mercados financeiro e de capitais.

É importante salientar aqui que as legislaçóes posteriores à de 1994 que tratam do IOF não alteram nenhuma disposição sobre a sua incidência nas operações cambiais. Todas as mudanças posteriores são relativas à alíquota cobrada, de acordo com os interesses de política econômica em dado momento, como fica claro na Lei ${ }^{\circ} 8.894 / 94$, art. $5^{\circ}$.

A análise do histórico das alíquotas do IOF nos permite perceber o comportamento da legislação que regula a entrada e 
a saída dos fluxos de capitais estrangeiros. Assim, é possível inferir a tendência das medidas que controlam os capitais, isto é, se possui caráter liberalizante ou restritivo. A alíquota cobrada sobre operaçóes de câmbio de $25 \%$ sobre o valor de liquidação permaneceu vigente até meados de 1997, incidindo sobre remessas de moeda estrangeira relativas à importação de bens e serviços, segundo a Lei $n^{\circ}$ 8.894/94.

A legislação que regula as remessas destinadas ao cumprimento de obrigações de administradoras de cartão de crédito - decorrentes de aquisição de bens e serviços do exterior efetuados por seus usuários - sofreu várias alteraçoos nas alíquotas durante os últimos anos. De dezembro de 1997 até março de 1999, a alíquota vigente era de $2 \%$ sobre o valor da operação cambial; sendo reajustada para 2,5\% a partir de 17 de março de 1999 . No começo de fevereiro de 2000 , voltou a vigorar a alíquota de $2 \%$, e oito anos após, no primeiro dia útil de 2008 , foi reajustada novamente para $2,38 \%$.

A Portaria $\mathrm{n}^{\circ} 28$, de 8 de fevereiro de 1996 , atribuída pelo MF, fixou as seguintes alíquotas - calculadas sobre o ingresso de moeda estrangeira relativos a operaçóes de empréstimo - que se diferenciavam de acordo com o prazo médio da aplicação: $5 \%$ sobre os capitais com prazo médio inferior a três anos; $4 \%$ sobre os capitais com prazo entre três e quatro anos; $2 \%$ sobre os capitais com prazo médio igual a quatro anos e inferior a cinco anos; $1 \%$ sobre capitais com prazo médio igual a cinco anos e inferior a seis anos. $\mathrm{O}$ ingresso de moedas estrangeiras referente a operações de empréstimo, com prazo médio superior a seis anos, era isento do IOF. As operaçóes interbancárias realizadas entre instituiçóes financeiras no exterior e bancos credenciados a operar em câmbio no Brasil foram taxadas em 7\%; a mesma alíquota que incidiu sobre as disponibilidades de curto prazo no país pertencentes aos residentes no exterior naquele momento. Meses depois, em 31 de outubro de 1996, a Portaria ${ }^{\circ} 241$ do MF altera as alíquotas para baixo até então vigentes sobre o ingresso de moeda estrangeira para fins de empréstimos, numa tendência clara de liberalização dos fluxos internacionais de capitais. A partir de então, as alíquotas válidas eram as seguintes: $3 \%$ sobre os fluxos com prazo médio inferior a três anos; $2 \%$ sobre os capitais com prazo médio entre três e quatro anos; e $1 \%$ sobre os capitais entre quatro e cinco anos. Os fluxos destinados a empréstimos com prazo superior a cinco anos foram isentos do IOF.

Em abril de 1997, as autoridades monetárias continuaram a flexibilizar as condições de ingresso de capitais estran- 
geiros no país através da Portaria $\mathrm{n}^{\circ} 85$ do Ministério da Fazenda. Essa medida instituiu novas alíquotas sobre os fluxos de capitais com a mesma tendência anterior. Os empréstimos em moeda estrangeira, independentemente do prazo, foram isentos de qualquer pagamento do IOF, e as operaçóes interbancárias, realizadas entre instituições financeiras estrangeiras e bancos brasileiros credenciados a operar com câmbio, foram taxados em $2 \%$ em detrimento da taxação de $7 \%$ imposta pela medida vigente anterior. A constituição de disponibilidade de curto prazo no país por residentes no exterior também teve reajuste semelhante: de $7 \%$ caiu para $2 \%$ sobre o capital. Na sequência, a Portaria ${ }^{\circ} 56$, de 12 de março de 1999, fixou a alíquota sobre operaçóes interbancárias realizadas entre instituições financeiras no exterior e bancos nacionais credenciados a operar em câmbio em $0,5 \%$. A mesma alíquota foi instituída sobre a transferência de recursos do exterior para aplicação em fundo de renda fixa. Atualmente, a alíquota vigente é de 5,38\% sobre empréstimos em moeda com os prazos médios mínimos de até noventa dias (Decreto $\mathrm{n}^{\circ} 6.339$, de 3 de janeiro de 2008); 2,38\% sobre operaçóes de câmbio destinadas ao cumprimento de obrigaçóes de administradoras de cartão de crédito (Decreto ${ }^{\circ}$ 6.345, de 4 de janei- ro de 2008); $0,38 \%$ sobre operações relativas ao pagamento de importaçáo de serviços (Decreto $\mathrm{n}^{\circ}$ 6.931, de 12 de março de 2008), entre outras.

À medida que os mercados financeiros se tornam cada vez mais integrados e com o surgimento de inovações financeiras, a legislação brasileira se modifica na tentativa de conseguir oferecer o respaldo necessário diante da complexidade do mercado. Durante a década de 2000, alterações sobre a legislaçáo que regula o IOF se tornaram cada vez mais recorrentes. A recente medida mais abrangente sobre $\mathrm{o}$ IOF foi o Decreto $n^{\circ}$ 6.306, de 14 de dezembro de 2007, que em seu texto trata sobre disposições das alíquotas referentes às operaçóes cambiais, por exemplo: moeda ingressa para fins de empréstimos; operações referentes às operadoras de cartão de crédito; pagamento de importação de serviços; liquidaçóes de operaçóes de câmbio para ingressos e retornos de recursos aplicados por investidores estrangeiros; receitas de exportação de bens e serviços, etc.

Entre 2008 e 2009, as operaçóes de câmbio relativas a transferências do e para o exterior, inclusive por meio de operações simultâneas, realizadas por investidor estrangeiro, para aplicação nos mercados financeiros e de capitais, tiveram suas alíquotas alteradas para zero, conforme disposto no Decreto no 6.613, de 22 de outu- 
bro de 2008 (que altera o Decreto $n^{\circ}$ 6.306, de 14 de dezembro de 2007). A mesma alteraçáo ocorreu sobre operaçáo de compra de moeda estrangeira por instituição autorizada a operar no mercado de câmbio, contratada simultaneamente com uma operação de venda, bem como os recursos captados a título de empréstimos e financiamentos externos. Isso é reflexo do período de auge da crise financeira.

Diante da crise mundial, que provocou enorme fuga de capitais das economias emergentes seguida por forte enxurrada de influxos financeiros, o governo brasileiro reagiu, alterando a alíquota do IOF. Conforme Decreto $\mathrm{n}^{\circ}$ 6.983, de 19 de setembro de 2009, sobre as operaçóes de câmbio para ingresso de recursos no país, realizadas por investidor estrangeiro, para aplicação no mercado financeiro e de capitais passaram a ser cobradas alíquotas de $2 \%$.

Outra medida como resposta à crise foi aplicada, a partir do Decreto $\mathrm{n}^{\circ}$ 7.011, de 18 de novembro de 2009, que também altera o Decreto ${ }^{\circ}$ 6.306, de 14 de dezembro de 2007, e institui a cobrança do IOF à alíquota de 1,5\% na cessão de açóes que sejam admitidas à negociação em bolsa de valores localizada no Brasil, com o fim específico de lastrear a emissão de depositary receipts negociados no exterior.

Mais recentemente ainda, o Decreto $\mathrm{n}^{\circ} 7.412$, de 30 de dezembro de 2010, al- terou a alíquota do IOF sobre operaçóes de câmbio contratadas por investidor estrangeiro, para ingresso de recursos no país, para constituição de margem de garantia, para $6 \%$. Ademais, nas liquidações de operaçóes de câmbio contratadas a partir de $1^{\circ}$ de janeiro de 2011 por investidor estrangeiro, para aquisiçẫo de cotas de fundos de investimento em participaçóes e de fundos de investimento em cotas dos referidos fundos, bem como por meio de cancelamento de depositary receipts e através da mudança de regime do investidor estrangeiro, de investimento direto para investimento em açóes negociáveis em bolsa de valores; a alíquota passou a ser de $2 \%$.

Já em 2011, o Decreto no 7.456, do Ministério da Fazenda, de 28 de março, elevou para $6 \%$ a alíquota de IOF sobre as captaçóes externas de até 360 dias (as captações externas com prazo inferior a 90 dias já eram tributadas com alíquota de IOF de 5,38\%). Finalmente, a partir de 6 de abril do mesmo ano, o IOF de $6 \%$ passa também a incidir sobre empréstimos externos de até dois anos e para repactuação e assunção de dívidas. Assim, estas últimas medidas ${ }^{7}$ foram consideradas importantes para restringir os fluxos especulativos de capitais que retornaram com toda força após a crise financeira internacional, que foi sentida com maior
${ }^{7}$ Ao longo de 2011, o Brasil também adotou algumas medidas prudenciais, como o aumento de requerimentos de capitais aos bancos para certas operaçóes de crédito e aumentou requerimentos de reserva não remunerados sobre depósitos a prazo.

Para saber sobre outras medidas prudenciais, ver FUNDAP (2011). 
força entre 2007 e 2009, iniciando um novo ciclo de expansão da liquidez global.

\section{4_Análise empírica: inter-relação entre risco-país, IOF, fluxos de capitais, câmbio e juros entre 1995 e 2011}

Ao longo da década de 1990 e mais recentemente a partir de 2008, o Banco Central do Brasil - via regulamentação do mercado de câmbio e de capitais estrangeiros e a Receita Federal brasileira - por meio da taxação via IOF - reagiram às conjunturas desfavoráveis diante de um cenário de crises financeiras recorrentes em âmbito internacional. Todavia, as medidas adotadas não representaram restrição efetiva da circulação de capitais, o que é facilmente observável a partir da dinâmica da conta financeira do balanço de pagamentos no Brasil, que se mostra constante e fortemente volátil. Após a eclosão da crise financeira internacional de 2008/09, apresentou-se uma saída recorde de capitais, especificamente em outubro de 2008; seguida de expressiva entrada de fluxos de Portfólio e Outros Investimentos. Em outras palavras, o IOF e a legislação cambial não constituíram barreiras à movimentação de capitais, sobretudo os de curto prazo. Ademais, não se observou mudança na composição dos influxos de capitais, em direção a fluxos de longo prazo. Desse modo, a eficácia das medidas de controles de capitais adotadas no Brasil deve ser novamente analisada.

Se realmente a taxação do IOF tem caráter pouco reflexivo sobre os movimentos de capitais, especialmente no mercado de capitais e no mercado futuro, sugere-se que é necessária análise prévia do perfil de cada fluxo de entrada de capitais para que a taxação seja aplicada de maneira mais adequada e direcionada aos fluxos mais voláteis.

Portanto, pretende-se investigar com base nesse argumento a adoção de controle de capitais no Brasil até o momento, via IOF, e suas inter-relações com o câmbio, os fluxos de capitais, os juros, e o risco-país. A justificativa para inclusão dessas variáveis é a tentativa de incorporar na análise empírica os elementos que mais estão relacionados com alteraçóes da dinâmica dos fluxos de capitais direcionados para a economia brasileira, a fim de detectar qual deles exerce maior influência sobre esse movimento.

Ao não adotar medidas mais concretas de controle de capitais, o governo brasileiro deixa o livre movimento dos fluxos de capitais "contaminado" pela influência do diferencial de juros e pela expectativa de valorização cambial. Acredita-se na necessidade de uma taxação mais ampla dos fluxos financeiros, de limites 
sobre margens e depósitos para os capitais que entram no país, de uma regulamentação das operaçôes de bancos em moeda estrangeira (a regulação prudencial); sem falar da necessidade de controlar operaçôes da Bolsa de Valores e do mercado futuro. Assim, vamos examinar a relação entre a arrecadação do IOF e a dinâmica dos fluxos de capitais, com o intuito de se discutir se são necessários controles mais abrangentes de capitais no Brasil e que, assim, poderiam ser mais eficazes (a depender dos resultados empíricos da análise proposta) que a taxaçáo do IOF.

\section{1_Análise preliminar da relação entre fluxos de capitais e IOF}

Ao se adotar a taxação via IOF como uma medida de restrição da especulação que caracteriza a entrada de capitais estrangeiros no Brasil, esperar-se-ia uma relação próxima entre a arrecadação do IOF e os movimentos dos fluxos de capitais. Isto é, o esperado é que a cobrança de uma alíquota maior de IOF, e o conseqüente aumento em sua arrecadação, desestimulasse os investidores internacionais que passariam a direcionar menos recursos para a economia brasileira, limitando o potencial de especulação subjacente aos fluxos financeiros. A lógica por trás dessa medida é que o Imposto sobre Operaçóes Financei- ras funcionasse como uma barreira sobre a entrada de capitais estrangeiros.

Para a análise do que ocorreu na economia brasileira, a partir do uso do IOF como medida de controle de capitais, observaremos com mais detalhes a dinâmica de duas séries da subconta financeira "Investimentos Estrangeiros em Carteira", pertencente ao balanço de pagamentos brasileiro, quais sejam: os Títulos de Renda Fixa e as Ações de Companhias Brasileiras. A justificativa para a escolha dessas duas séries se dá com base na análise de estudos das subcontas mais voláteis do balanço de pagamentos brasileiro (Munhoz \& Corrêa, 2009; Munhoz \& Libânio, 2009) $)^{8}$ e por serem os fluxos que se tornaram alvo das últimas alterações de alíquotas do IOF, justamente por conta do viés de curto prazo.

Todavia, observa-se pelo Gráfico 1 que, embora tenha ocorrido um boom sobre a arrecadação do IOF em período recente - resultado das políticas restritivas via aumento de suas alíquotas nos anos de 2008 a 2011, conforme se mostra no Anexo A -, a dinâmica dos fluxos financeiros permaneceu a mesma, isto é, apresentando movimentos bruscos de entrada e saída de capitais (forte volatilidade desses fluxos).

A interpretação diante dessa análise é a que a relação entre arrecadação do
${ }^{8}$ Valendo-se de uma análise de 50 subcontas financeiras, os autores detectaram que os Investimentos Estrangeiros em Carteira, via títulos de renda fixa, e os Outros Investimentos Estrangeiros, via empréstimos e financiamentos e moeda e depósitos, foram as subcontas que apresentaram maior volatilidade durante o período entre 1995 e 2008. Além disso, essas subcontas são as principais fontes de influxos de recursos, tendo grande participaçáo relativa no total da conta financeira do balanço de pagamentos do Brasil. 
Gráfico 1_Arrecadação do IOF sobre operações de câmbio* e Fluxos de Investimentos Estrangeiros em Renda Fixa (IECRF) e Ações (IECA)**: janeiro 1995 a dezembro 2011

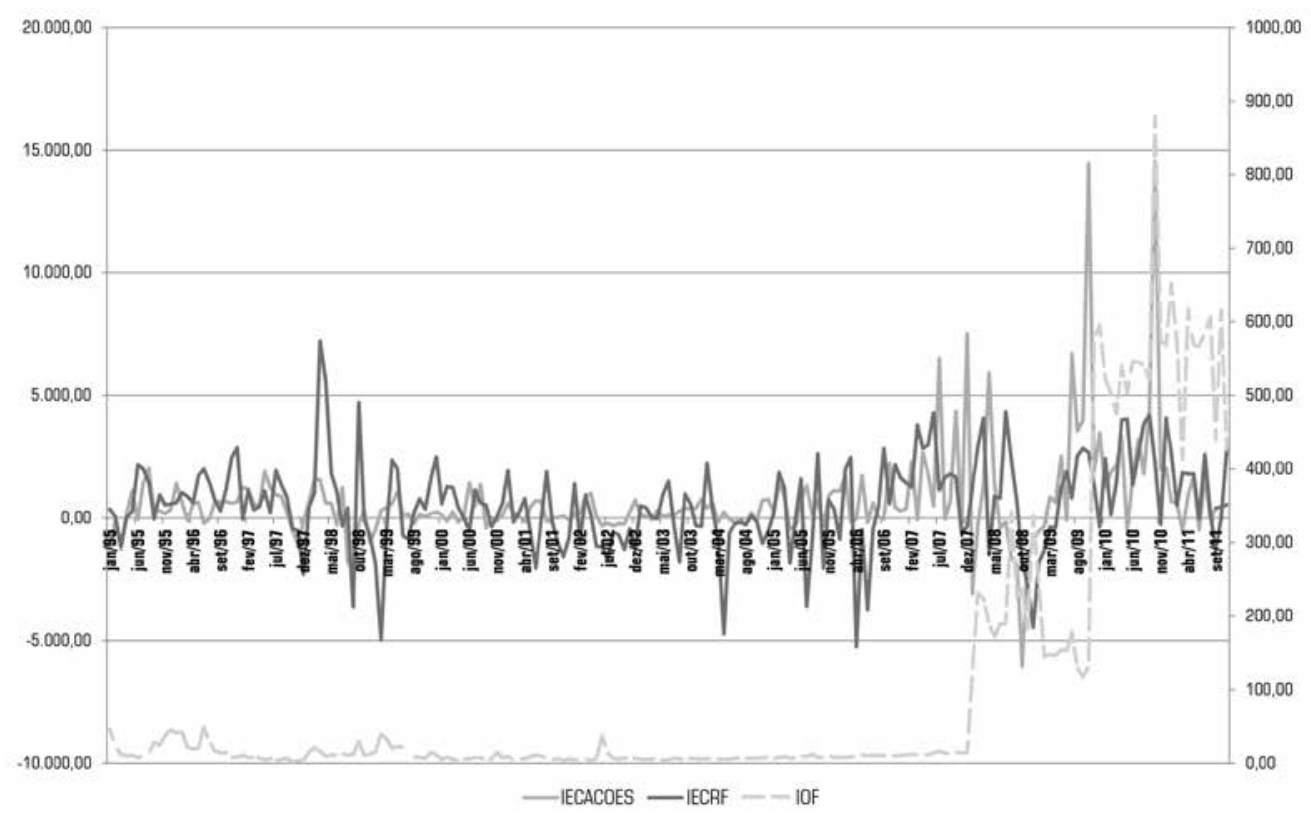

Fonte: Receita Federal do Brasil e Banco Central do Brasil. *em R \$ milhốes. **em U\$ milhốes.

IOF e fluxos de capitais é fraca. Não obstante, essa é apenas uma interpretação da análise descritiva e gráfica de parte dos dados da conta financeira brasileira. Para confirmamos tal (pouca/fraca) relação, procederemos à análise dessa inter-relação por meio da metodologia VAR. Cabe destacar que as alteraçóes das alíquotas do IOF, adotadas como medida de política monetária e cambial, tiveram impactos importantes no que toca à política fiscal do país. Como se observa no Gráfico
1, ocorreu elevação brusca no patamar da arrecadação fiscal via esse imposto a partir da medida adotada, o chamado "controle de capitais brasileiro".

\section{2_Fonte, tratamento dos dados e metodologia}

A taxa de câmbio foi selecionada por mostrar relaçáo direta do cenário internacional com os movimentos dos fluxos de capitais e principalmente com as alteraçóes na regulamentação do mercado cambial e de capi- 
tais estrangeiros. A série da taxa de câmbio foi obtida no sistema gerenciador de séries temporais do Banco Central do Brasil (BCB). A taxa de câmbio corresponde à taxa de câmbio real - R \$ / US\$ - sendo o câmbio cotado no seu valor de compra, câmbio comercial, e pela média. A variável selecionada corresponde à série no 3.697 do $\mathrm{BCB}$.

As séries da conta financeira do balanço de pagamentos também foram obtidas no BCB. Utilizamos a variável referente aos fluxos de capitais de Investimento Estrangeiro em Carteira (IEC), especificamente duas subcontas: ações de companhias brasileiras e renda fixa (saldos líquidos), conforme análise preliminar do alvo das taxações do IOF. As variáveis selecionadas correspondem às séries $\mathrm{n}^{\circ}$ 8.217 e 8.222 do $\mathrm{BCB}$, em US\$ milhóes.

$A$ arrecadação do IOF foi selecionada, uma vez que pode ser considerada uma proxy do controle de capitais adotado no Brasil. Uma alteração na alíquota do IOF é diretamente sentida na arrecadação bruta do imposto. ${ }^{9}$ Mais especificamente, foi selecionada a arrecadação do IOF (Imposto sobre Operações de Crédito, Câmbio e Seguro, ou Relativas a Títulos e Valores Mobiliários) sobre operaçóes cambiais, já que são essas operaçôes que têm relação direta com os movimentos de capitais estrangeiros. Os dados dessa arrecadação correspondem à sua receita bru- ta em preços correntes, em $\mathrm{R} \$$ milhões, registrada pelo conceito de competência, cuja fonte é a Receita Federal. ${ }^{10}$

Por sua vez, a taxa de juros foi selecionada, visto que o nível de juros tem relação direta com a atração dos fluxos de capitais. Há, portanto, um canal direto entre a livre mobilidade de capitais e a política nacional de juros. A taxa de juros utilizada é a taxa nominal SELIC acumulada no mês (em \%), que corresponde à série no 4.390 do $\mathrm{BCB}$.

$\mathrm{O}$ risco-país foi calculado com base no EMBI+. O Emergent Markets Bonds Index Plus (EMBI+) é um indicador calculado pelo JP Morgan para avaliar o prêmio de risco de títulos de economias emergentes em relação aos títulos do Tesouro dos Estados Unidos. Assim, justifica-se seu uso na presente análise empírica por ter associação com os fluxos financeiros de investidores estrangeiros, que observam o movimento do risco-país ao investir em economias emergentes. Nesse caso, os dados foram extraídos da base de dados do banco de investimentos americano J. P. Morgan, que disponibiliza os dados EMBI+ em pontos base.

Finalmente, foi adotada também uma variável exógena, as reservas internacionais, para controlar a relação endógena entre as variáveis acima selecionadas. Tal escolha se justifica, pois o nível de
${ }^{9}$ Alguns estudos, como Silva e Resende (2010), apontam que a alíquota do IOF seria um melhor indicador para analisar controles de capitais no país e, assim, para a análise do processo de liberalização nesse caso. Entretanto, não há disponibilidade de dados sobre a alíquota do IOF de forma sistematizada, o que dificulta esta análise.

${ }^{10}$ Os dados da arrecadação do IOF - operaçóes cambiais - foram fornecidos pelo coordenador de Previsão e Análise da Receita Federal, Raimundo Eloi Carvalho. 
${ }^{11}$ Também estimamos o mesmo modelo sem dummy, e não houve mudança significativa dos resultados.

${ }^{12}$ A Tabela I do Anexo B apresenta as estatísticas descritivas das séries utilizadas na aplicação do modelo VAR.

${ }^{13}$ Os procedimentos econométricos para as ADV e FIR foram feitos utilizando-se o software E-Views 7. reservas tem relação com os fluxos de capitais direcionados para a economia brasileira, mas relação esta que é paralela às inter-relaçóes acima propostas. Assim, essa se tornou uma variável-controle, sendo, portanto, exógena. A série utilizada foram as reservas internacionais em seu conceito liquidez, em U\$ milhóes, que corresponde à série $\mathrm{n}^{\circ} 3.546$ do BCB. Ademais, utilizamos uma variável dummy separando o regime de taxa de câmbio administrado (até o final de 1998), do regime de taxa de câmbio flutuante. ${ }^{11}$

Os dados vão de janeiro de 1995 a dezembro de 2011, totalizando 204 observaçóes. ${ }^{12} \mathrm{~A}$ escolha do recorte temporal se deve ao intuito de se observar um período caracterizado por momentos de elevada vulnerabilidade externa, haja vista a conjuntura de sucessões de crises financeiras no período em análise, incluindo a crise internacional atual. Ademais, optamos pela análise a partir do Plano Real, uma vez que os dados até 1994 poderiam distorcer os resultados, em razão da relação das variáveis analisadas com a variação do nível de preços.

A análise será realizada por meio da metodologia de vetores autorregressivos (Modelo VAR irrestrito). Essa metodologia é útil para os objetivos aqui propostos, visto que possibilita a análise das relaçóes dinâmicas entre as variáveis selecionadas, que são endógenas, sem definir a priori a ordem de determinação e a causalidade entre elas. Isto é, podemos valendo-nos desse método analisar a interação dinâmica das variáveis macroeconômicas pertinentes aos movimentos dos fluxos financeiros, sem que se assuma, ex ante, relaçáo causal entre uma ou mais variáveis no modelo.

Ademais, o instrumental de análise subjacente aos modelos VAR permite analisar de forma empírica qual a participação de cada uma das variáveis do modelo no entendimento de cada choque individual nas $k$ variáveis componentes do modelo (análise de decomposição de variância - ADV), e ainda, permite analisar a sensibilidade das variáveis econômicas, por meio de simulação, a choques específicos (análise das funçóes impulso-resposta - FIR). ${ }^{13}$

Como de praxe, iniciamos a análise com os tradicionais testes de raiz unitária para as variáveis em questão, todas reportadas na Tabela 1 (Teste Augmented Dickey-Fuller - ADF - e Teste Philips-Perron - PP). Observando os níveis de significância de $5 \%$ e $1 \%$, podemos ver pela Tabela 1 que apenas as séries de investimentos estrangeiros em carteira, açóes e renda fixa, respectivamente (IECA e IERF), apresentaram-se estacionárias em nível, enquanto para outras foi necessária a aplicação de uma defasagem, ou seja, são integradas de 
Tabela 1_Testes de raiz unitária

\begin{tabular}{|c|c|c|c|c|c|c|c|c|c|c|}
\hline Variável & Defasagem & Constante & Tendência & t-ADF & t-probit & Bandwidth & Constante & Tendência & t-PP & t-probit \\
\hline DCAMBIO & 0 & $\operatorname{sim}$ & $\operatorname{sim}$ & -9.95 & 0.00 & 3 & $\operatorname{sim}$ & $\operatorname{sim}$ & -9.91 & 0.00 \\
\hline IECA & 1 & $\operatorname{sim}$ & $\operatorname{sim}$ & -6.96 & 0.00 & 6 & $\operatorname{sim}$ & $\operatorname{sim}$ & -11.81 & 0.00 \\
\hline IECRF & 0 & $\operatorname{sim}$ & $\operatorname{sim}$ & -9.60 & 0.00 & 4 & $\operatorname{sim}$ & $\operatorname{sim}$ & -9.69 & 0.00 \\
\hline DIOF & 1 & $\operatorname{sim}$ & não & -13.80 & 0.00 & 8 & $\operatorname{sim}$ & $\operatorname{sim}$ & -22.00 & 0.00 \\
\hline DSELIC & 0 & não & não & -15.59 & 0.00 & 7 & $\operatorname{sim}$ & $\operatorname{sim}$ & -15.83 & 0.00 \\
\hline DEMBI & 0 & $\operatorname{sim}$ & $\operatorname{sim}$ & -9.87 & 0.00 & 0 & $\operatorname{sim}$ & $\operatorname{sim}$ & -9.87 & 0.00 \\
\hline DRESERVAS & 0 & $\operatorname{sim}$ & $\operatorname{sim}$ & -9.89 & 0.00 & 8 & $\operatorname{sim}$ & $\operatorname{sim}$ & -10.41 & 0.00 \\
\hline
\end{tabular}

Fonte: Saída do Eviews. *A variável risco-país foi estacionária ao nível de $10 \%$ de significância.

ordem 1 - I(1). Assim, as séries do câmbio (DCAMBIO), da arrecadação do IOF (DIOF), do risco-país (DEMBI), da taxa de juros (SELIC) e das reservas internacionais (DRESERVAS) foram transformadas em suas primeiras diferenças.

A seleção dos modelos se baseou em um procedimento de redução do número de defasagens de cada modelo, tendo-se como referência os resultados dos critérios de informação de Akaike (AIC) e Schwarz (SC), conjuntamente com a análise dos resíduos do modelo. Conforme se pode verificar, com base na Tabela 2, iniciamos a seleção do modelo com cinco defasagens e reduzimos até zero defasagem, tomando os valores dos critérios de informação como referência.
A Tabela 2 mostra que o modelo mais adequado é um VAR com 1 defasagem, segundo os critérios AIC e HQ. Além disso, testes de diagnósticos adicionais dos resíduos corroboraram a escolha dessa defasagem única, conforme Tabela 3.

\section{3_Resultados do Modelo VAR}

Nesta seção, estudaremos o comportamento dos fluxos de capitais ante a choques no câmbio, no IOF, nos juros e no risco-país. As funções impulso-resposta traçam o efeito de um choque no tempo $t$ dos termos de erro de uma variável particular sobre os valores correntes e futuros das variáveis pertencentes ao modelo VAR (Enders, 2004). Mantendo-se todos os outros choques constantes, um 
Tabela 2_Seleção do modelo para estimação do VAR

\begin{tabular}{r|r|r|r|r}
\multicolumn{1}{c|}{ Sistema/Método } & Log-Likelihood & Aic & SC & HQ \\
\hline Sistema com 0 lag & -5486.602 & 55.82337 & $56.02336^{*}$ & 55.90433 \\
\hline Sistema com 1 lag & -5402.124 & $55.33121^{*}$ & 56.13118 & $55.65504^{*}$ \\
\hline Sistema com 2 lags & -5373.939 & 55.41055 & 56.81049 & 55.97726 \\
\hline Sistema com 3 lags & -5355.713 & 55.59099 & 57.59091 & 56.40058 \\
\hline Sistema com 4 lags & -5338.678 & 55.78353 & 58.38343 & 56.83599 \\
\hline Sistema com 5 lags & -5307.704 & $\ldots 5.83456$ & $\ldots .59 .03443$ & $57.12989 \ldots$
\end{tabular}

Fonte: Saída do Eviews. ${ }^{*}$ Indica a defasagem selecionada pelo critério.

AIC: Akaike information criterion; SC: Schwarz information criterion;

HQ: Hannan-Quinn information criterion.

Tabela 3_Teste de Normalidade Jarque-Bera

\begin{tabular}{|c|c|c|c|}
\hline Component & Jarque-Bera & df & Prob. \\
\hline 1 & 243.7417 & 2 & 0.0000 \\
\hline 2 & 1055.453 & 2 & 0.0000 \\
\hline 3 & 368.3362 & 2 & 0.0000 \\
\hline 4 & 2552.430 & 2 & 0.0000 \\
\hline 5 & 2973.043 & 2 & 0.0000 \\
\hline Joint & 7240.965 & 12. & 0.0000 \\
\hline
\end{tabular}

Fonte: Saída do Eviews. variáveis inseridas no VAR, optamos pelo uso das Funçóes Generalizadas de Resposta a Impulso, desenvolvidas por Pesaran \& Shin (1998), que evitam o uso da decomposição de Cholesky para definição do ordenamento correto das variáveis. Ademais, tendo em vista que o objetivo desta análise empírica é observar a dinâmica dos fluxos de capitais alvos da taxação do IOF perante as alteraçóes de sua arrecadação em comparação às respostas desses fluxos diante dos movimentos do câmbio, risco-país e taxa de juros; observamos as respostas especificamente dos fluxos Investimentos Estrangeiros em Carteira, de Ações (IECA) e Renda Fixa (IECRF).

Pelo Gráfico 2a, nota-se pequena queda dos fluxos de investimentos estran- 
geiros em açóes de companhias brasileiras (IECA) diante de um choque na taxa de juros (DSELIC), e, a partir do segundo mês do choque, esses fluxos passam a aumentar, voltando ao seu nível normal no terceiro mês após o choque. Por outro lado, a resposta dos fluxos de IECA diante de choques da taxa de câmbio (DCAMBIO) e do risco-país (DEMBI) é positiva e com efeitos duradouros ao longo do tempo. Há aumento brusco desses fluxos durante os seis primeiros meses após os choques de câmbio. Os impulsos do EMBI geram resposta positiva dos fluxos de IECA, e, após dois meses, o choque do risco-país leva a quedas desses fluxos especulativos.

Todavia, nota-se reação mais rápida e menos intensa dos mesmos fluxos quando o choque é dado pela arrecadação do IOF (DIOF). Quando o IOF aumenta, os influxos de capitais desse tipo caem rapidamente, mas em magnitude menor, e, após três meses, os fluxos já voltam ao seu nível anterior ao choque. Assim, podemos dizer que a inter-relação entre fluxos de capitais e IOF é fraca quando analisamos a aplicação da modelagem VAR por meio das funçôes de impulso-resposta.

Por sua vez, observamos as respostas dos fluxos de renda fixa (IECRF) perante os impulsos generalizados das demais variáveis. Os fluxos de IECRF caem aproximadamente U\$200 milhóes dian- te dos choques do risco-país (DEMBI) e caem para além desse montante ante os choques do câmbio (DCAMBIO), ao passo que variam aproximadamente U\$ 100 milhões em relação aos choques do IOF. Ademais, mais uma vez, as respostas de IECRF aos impulsos do IOF são mais rápidas, conforme Gráfico 2b.

Para a Análise de Decomposição de Variância (ADV), este trabalho se valeu da realização do teste de causalidade e exogeneidade de Granger/Block como melhor aproximaçáo para definir um ordenamento estatisticamente consistente das variáveis no VAR. Assim, foi estabelecida a seguinte ordenação (Cholesky) das variáveis no VAR (das mais endógenas para as mais exógenas): DEMBI, DCAMBIO, DSELIC, DIOF, IECA, IECRF.

As Análises da Decomposição das Variâncias (ADV) também trazem resultados interessantes quanto ao comportamento dos fluxos de capitais em relação ao IOF, como mostram os resultados apresentados na Tabela 4. Antes de discutir os resultados dessas análises, cabe colocar que a Análise da Decomposição da Variância mostra que os erros de previsão de dada variável podem ser decompostos pelos efeitos das demais variáveis, dizendo-nos a proporção dos movimentos em uma sequência em razão dos "próprios" choques versus os choques das outras variáveis. Vamos destacar 


\section{Gráfico 2a_FIR: Resposta dos fluxos de IECA aos impulsos generalizados}

Response to Generalized One S.D. Innovations
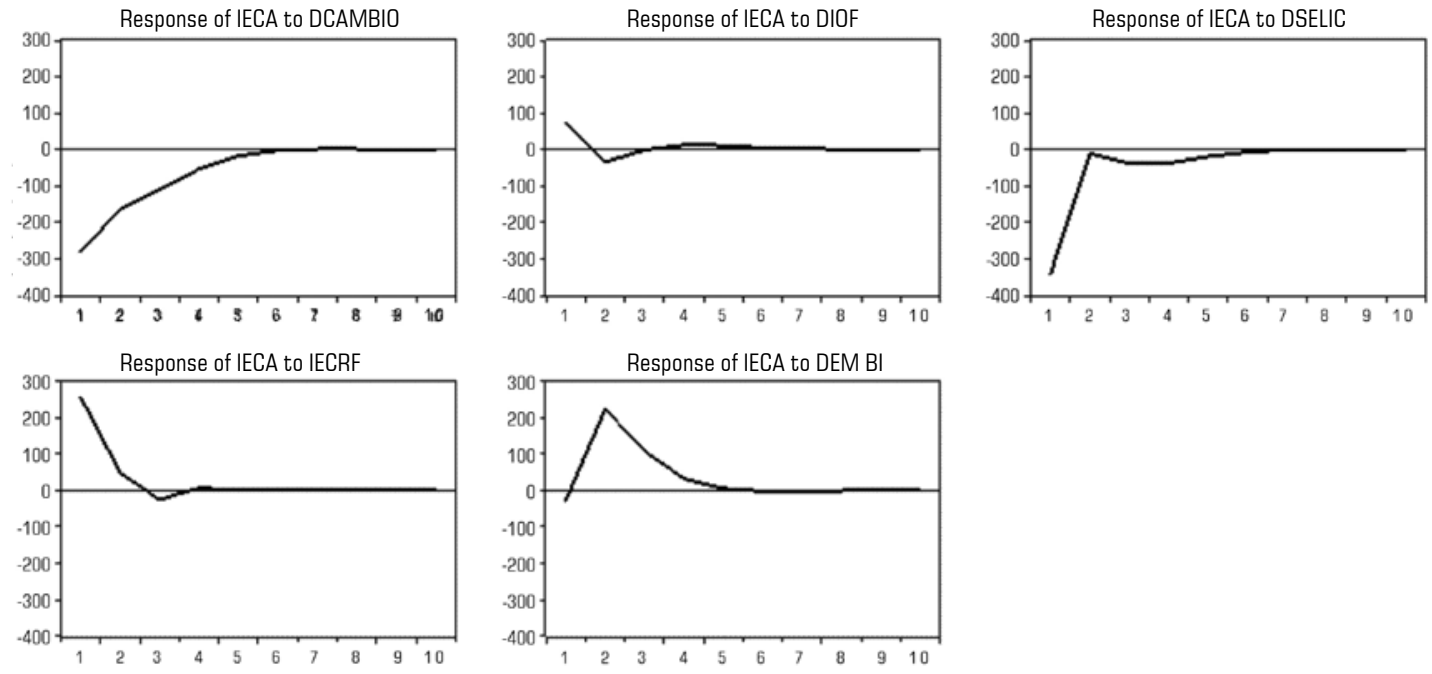

\section{Gráfico 2b_FIR: Resposta dos fluxos de IECRF aos impulsos generalizados}

Fonte: Saída do Eviews. Nota: Funçōes

Generalizadas de

Resposta a Impulso, conforme Pesaran \& Shin (1998).

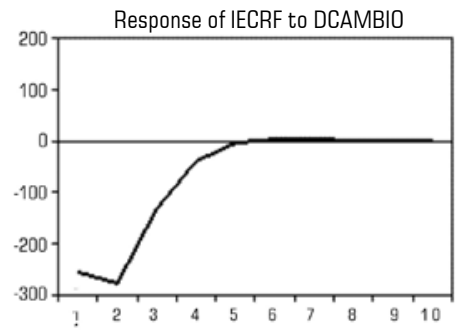

Response to Generalized One S.D. Innovations
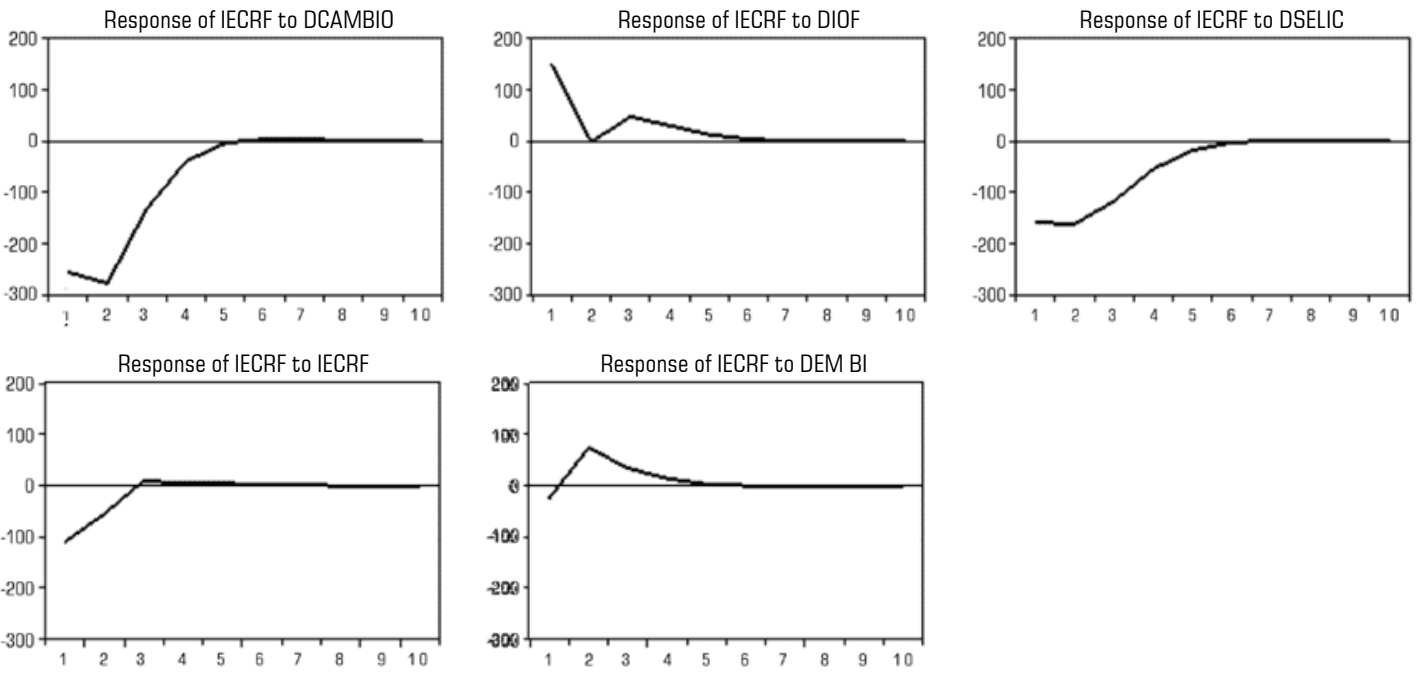
Tabela 4_Análise de Decomposição da Variância

Variance Decomposition of IECA:

\begin{tabular}{c|c|c|c|c|c|c|c}
\hline Período & \multicolumn{1}{|c|}{ S.E } & DCAMBIO & DSELIC & DEMBI & DIOF & IECA & IECRF \\
\hline 1 & 1778.850 & 0.718539 & 0.377357 & 3.656494 & 1.845837 & 93.40177 & 0.000000 \\
\hline 5 & 1822.233 & 1.988684 & 0.468873 & 3.587075 & 1.847917 & 90.33999 & 1.767461 \\
\hline $\mathbf{1 0}$ & $\mathbf{1 8 2 2 . 2 6 7}$ & $\mathbf{1 . 9 8 8 7 3 3}$ & $\mathbf{0 . 4 7 0 0 4 0}$ & $\mathbf{3 . 5 8 8 6 3 5}$ & $\mathbf{1 . 8 4 7 9 7 7}$ & $\mathbf{9 0 . 3 3 6 7 2}$ & $\mathbf{1 . 7 6 7 8 9 4}$ \\
\hline
\end{tabular}

Variance Decomposition of IECRF:

\begin{tabular}{c|c|c|c|c|c|c|c}
\hline Período & \multicolumn{1}{|c|}{ S.E } & DCAMBIO & DSELIC & DEMBI & DIOF & IECA & IECRF \\
\hline 1 & 1499.014 & 1.930465 & 1.004019 & 1.127329 & 0.673278 & 0.199007 & 95.06590 \\
\hline 5 & 1570.778 & 4.268754 & 1.107413 & 2.788483 & 0.774436 & 0.226923 & 90.83399 \\
\hline $\mathbf{1 0}$ & $\mathbf{1 5 7 0 . 8 1 5}$ & $\mathbf{4 . 2 7 0 1 1 1}$ & $\mathbf{1 . 1 0 8 2 7 4}$ & $\mathbf{2 . 7 8 8 8 1 9}$ & $\mathbf{0 . 7 7 4 4 6 0}$ & $\mathbf{0 . 2 2 6 9 2 2}$ & $\mathbf{9 0 . 8 3 1 4 1}$ \\
\hline
\end{tabular}

Ordem de Cholesky: DEMBI, DCAMBIO, DSELIC, DIOF, IECA, IECRF

Fonte: Saída do Eviews.

aqui apenas a decomposição da variância das variáveis IECA e IECRF, já que o objetivo com a análise ADV é mostrar como os fluxos de capitais especulativos reagem diante dos choques das outras variáveis.

Nota-se, pela Tabela 4, que há inércia dos choques da variável IECA e IECRF sobre elas mesmas. Não obstante, decorridos 10 períodos, choques da variável DCAMBIO explicam aproximadamente $2 \%$ da variância dos fluxos de IECA e 4,3\% dos fluxos de IECRF, sendo assim, a variável que mais afeta os fluxos financeiros em análise. A variável EMBI explica aproximadamente $4 \%$ e $3 \%$ da variância de IECA e
IECRF, respectivamente. Enquanto isso, a variável DIOF explica apenas $2 \%$ aproximadamente da variância dos fluxos de IECA e menos ainda da variância dos fluxos de IECRF (nem 1\% da variância desses fluxos é explicada pelo IOF). Da mesma forma, os fluxos de IEC foram pouco afetados por choques da taxa de juros SELIC. Nesse sentido, a análise ADV sugere que o câmbio e o risco-país seriam as únicas variáveis com importância significativa para explicar a dinâmica dos fluxos de capitais aqui analisados. Enquanto isso, o IOF pouco afeta a dinâmica dos fluxos de capitais, mesmo considerando aqueles que 
foram alvo da política de controles, os Investimentos Estrangeiros em Carteira em Renda Fixa e Ações.

Portanto, a análise empírica por meio da aplicação do modelo VAR demonstra que a medida usada para controlar a entrada de capitais na economia brasileira tem pouca eficácia, sugerindo, assim, propostas alternativas para redução da instabilidade financeira do Brasil. O uso do IOF, tal como ele é utilizado hoje, mostra-se incapaz de conter o volume dos fluxos especulativos. Assim, concluímos que o elevado grau de abertura financeira apresenta o tamanho do desafio de conter a especulação subjacente aos fluxos financeiros. Dessa forma, reduzir tal grau de integração financeira pode ser o primeiro passo para proposição de políticas econômicas alternativas diante do cenário atual de instabilidade financeira.

\section{5_Considerações finais}

O debate acerca dos controles de capitais sempre foi polêmico e causador de divergências sob os diferentes matizes teóricos. Todavia, no atual contexto de crise financeira internacional, a regulação financeira tem sido apontada como proposta de política econômica perante esse cenário. Instituiçóes multilaterais que tradicionalmente advogavam a favor da plena con- vertibilidade de capitais já apontam os controles como importante ingrediente a ser adotado pelas economias emergentes. Assim, a discussão sobre as medidas que o Brasil vem adotando para restringir os fluxos financeiros tem encontrado grande aceitabilidade nos meios acadêmicos e políticos. Não obstante a convergência de opinióes sobre a desejabilidade dos controles, a discussão sobre a eficácia das diferentes medidas e a adequação dos instrumentos adotados ainda estáo longe de conclusivas. Desta maneira, o presente trabalho chega ao fim com a apresentação de quais medidas poderiam ser mais adequadas para o caso do Brasil.

Com base na análise empírica, foi observado que o IOF, conquanto medida de restrição dos influxos financeiros, não teve caráter estrito para constituição de barreiras à movimentação de capitais, sobretudo os de curto prazo. A consequência deste boom de influxos foi uma forte apreciaçáo da moeda doméstica nos dois últimos anos. Esses movimentos mostram, portanto, o impacto da pró-ciclicalidade dos fluxos financeiros sobre a volatilidade da taxa de câmbio, bem como o efeito do câmbio sobre os influxos de capitais. Assim, dado um elevado grau de abertura financeira da economia brasileira, a taxação via IOF tem-se revelado insuficiente para deter a trajetória de apreciação do 
real e assim continuará, caso o contexto de elevado apetite por risco (e, assim demanda por ativos de países emergentes) predomine nos próximos meses e/ou anos.

Desta forma, destaca-se a necessidade de medidas mais concretas que inibam efetivamente a especulação dos investidores estrangeiros. Isso poderia ser atingido por meio de um controle de entrada articulado com um controle sobre a saída de capitais e que fossem exógenos aos contextos de crises financeiras. De outra maneira, a imposição de um requerimento de reserva não remunerada (ou formas de quarentena) poderia ser mais enfatizada. Mais ainda, torna-se imperioso taxar amplamente os fluxos financeiros, a partir do estabelecimento de limites, margens e depósitos para os capitais que entram no país; regulamentar operaçóes de bancos em moeda estrangeira, bem como controlar o mercado futuro de dólares. Deve-se pensar também em políticas alternativas de controles de capitais, como os controles quantitativos, que se referem à proibição de toda e qualquer movimentação de capitais de cunho especulativo em determinado período de tempo. Essas seriam algumas possíveis estratégias para a economia brasileira e que estão incluídas no rol dos controles de capitais e da regulação prudencial.

Ademais, a análise prévia do perfil dos fluxos financeiros valendo-se do exa- me de cada subconta da conta financeira do balanço de pagamentos constitui importante estratégia para compreensão de quais capitais "atacar" durante a implementação de diferentes tipos de controle, bem como os seus possíveis "dribles". Muitas vezes, os fluxos financeiros mais taxados não são os mais especulativos e voláteis. É necessário, portanto, detalhado exame das características dos fluxos de capitais direcionados para o Brasil. Está claro que a desregulamentação financeira dos mercados permitiu significativa alavancagem de recursos e consequente perda financeira. O processo de regulamentação doméstica, cada vez mais salutar, deve passar por uma análise do perfil dos capitais ingressantes.

Com efeito, frisamos ainda a importância para a eficácia dos controles de capitais (quer sobre a entrada, quer sobre a saída de capitais) de que tais medidas sejam complementadas por outras estratégias de fomento ao desenvolvimento econômico, como a estabilidade política, o aumento do investimento em formação bruta de capital fixo, o incentivo à exportação e políticas desenvolvimentistas rumo à modificação de problemas estruturais do balanço de pagamentos brasileiro. A experiência internacional prova essa importante complementaridade. 


\section{Referências bibliográficas}

CARDOSO, E. \& GOLDFAJN, I. Capital flows to Brazil: The endogeneity of capital control. IMF Working Paper, 97, p. 115, Sept. 1997.

CARVALHO, B. \& GARCIA, M. Ineffective controls on capital inflows under sophisticated financial markets: Brazil in the nineties. NBER Working Paper, 12283, 2006.

\section{CARVALHO, F. C. \& SICSÚ, J.}

Controvérsias recentes sobre controles de capitais. Revista de Economia Politica, v. 24, n. 2, p. 163-184, abr./jun. 2004.

ENDERS, W. Applied econometric time series. 2. ed. New York: John Wiley, 2004. 480 p.

EPSTEIN, G. A.; GRABEL, I.; JOMO, S. K. Capital management tecniques in developing countries. In: Capital flight and capital controls in developing countries. Epstein, Gerald A. (Ed.). Edward Elgar, 2005.

FORBES, K. One cost of the Chilean capital controls: Increased financial constraints for smaller traded firms. Journal of International Economics, v. 71, n. 2, 2007a
FORBES, K. Capital controls. The new palgrave Dictionary of Economics, 2nd edition, Forthcoming, 2007b. Disponível em: <http://web.mit.edu/kjforbes/ www/articles1.html>. Acesso em: 18 ago. 2010.

FORBES, K. et al. Bubble thy neighbor: Direct and spillover effects of capital controls. Paper presented at 12th Jacques Polak Annual Research Conference. Nov. 10-11, 2011.

FUNDAP. O boom de capitais externos para o Brasil em 2011. Boletim de Economia, n. 5. 2011 Disponível em: <http://www. fundap.sp.gov.br>. Acesso em: nov. 2011.

GRABEL, I. International private capital flows and developing countries. In: HA-JOON, Chang (Ed.). Rethinking Development Economics, London: Anthem Press, 2003a. p. 325-345.

GRABEL, I. Averting crisis? Assessing measures to manage financial integration in emerging economies. Cambridge Journal of Economics, n. 27, p. 317-336, 2003 b.
INTERNATIONAL MONETARY FUND. Global Financial Stability Report, Apr. 2010. Disponível em: <http://www.imf.org/external/ pubs/ft/gfsr/2010/01/index.htm>. Acesso em: 30 abr. 2010.

INTERNATIONAL MONETARY

FUND. Recent experiences in managing capital inflows - CrossCutting themes and possible policy framework. IMF Policy Paper; Febr. 14, 2011.

MAGUD, N. \& REINHART, C. M. Capital controls: An evaluation. NBER Working Paper 11973, 2006.

MUNHOZ, V. C. V. \& CORRÊA, V. P. Volatilidade dos fluxos financeiros no Brasil: Uma análise empírica por meio do modelo ARCH (Autoregressive Conditional Heteroskedastic Model). Análise Econômica, Porto Alegre, v. 27, n. 52, p. 201-232, set. 2009.

MUNHOZ, V. C. V. \& LIBÂNIO,

G. Capital flight or volatile financial flows: Which one is the best indicator to measure Brazilian external vulnerability? In: 11th AHE Annual Conference, 2009, Kingston.

OCAMPO, J. A. \& PALMA, J. G. The role of preventative capital account regulations. IPD Working Papers, Columbia University, Jan. 2008.
OREIRO, J. Autonomia, fragilidade e equilíbrio: A teoria dos controles de capitais. In: SICSÚ, J.; FERRARI FILHO, F. Câmbio e controles de capitais: Avaliando a eficiência de modelos macroeconômicos. Rio de Janeiro: Elsevier, 2006.

OSTRY, J. et al. Capital inflows: The role of controls. IMF Staff Position Note. Feb. 19, 2010. International Monetary Fund.

PAULA, L. F.; OREIRO, J. L.; SILVA, G. Fluxos e controle de capitais no Brasil: Avaliação e proposta de política. In. Agenda Brasil: Políticas econômicas para o crescimento com estabilidade de preços. São Paulo: Manole, 2003.

PESARAN, M. H. \& SHIN, Y. Generalized impulse response analysis in linear multivariate models. Economics Letters, 58 , p. 17-29, 1998.

PRATES, D. M. A abertura financeira e vulnerabilidade externa da economia brasileira na década de noventa. 1997. f. Dissertação (Mestrado em Economia) - Instituto de Economia, Universidade Estadual de Campinas, Campinas, 1997. 
SILVA, G. J. C. \& RESENDE,

M. F. C. Eficácia dos controles de capitais no Brasil: Uma abordagem teórica e empírica alternativa. Estudos Econômicos (USP. Impresso), v. 40,

p. 617-649, 2010.

SOIHET, E. Índice de controle de capitais: Uma análise de legislação e dos determinantes ao fluxo de capital no Brasil no período de 1990-2000. 2002. 96 f. Dissertação (Mestrado em Economia) -

Fundação Getúlio Vargas, Rio de Janeiro, 2002.

TERRA, M. C. \& SOIHET, E.

Índice de controle de capitais:

Uma análise da legislação e seu impacto sobre o fluxo de capital no Brasil no período 1990-2000.

Estudos Econômicos, v. 36, n. 4, p. 721-745, 2006.

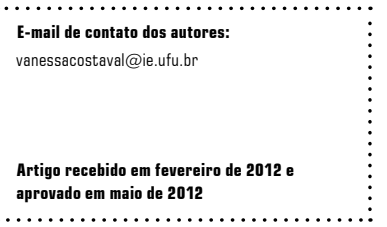




\section{Anexo A}

Quadro resumo com as principais alterações nas alíquotas do IOF

\begin{tabular}{|c|c|c|}
\hline Período & Operação & Alíquota \\
\hline Até $1^{\circ} .6 .97$ & Remessas de moeda estrangeira relativas à importação de bens e serviços. & $25,00 \%$ \\
\hline De 10.12 .97 a 16.3 .99 & \multirow{4}{*}{$\begin{array}{l}\text { Remessas destinadas ao cumprimento de obrigaçóes de administradoras de cartão de crédito } \\
\text { decorrentes de aquisiçấo de bens e serviços do exterior efetuados por seus usuários. }\end{array}$} & $2,00 \%$ \\
\hline De 17.3 .99 a 31.1 .00 & & $2,50 \%$ \\
\hline De $1^{\circ} .2 .00$ a 2.1 .08 & & $2,00 \%$ \\
\hline A partir de 3.1 .08 & & $2,38 \%$ \\
\hline \multirow{6}{*}{ De 9.2 .96 a 31.10 .96} & Ingressos de moeda estrangeira relativos a operaçôes de empréstimo com prazo médio inferior a três anos. & $5,00 \%$ \\
\hline & $\begin{array}{l}\text { Ingressos de moeda estrangeira relativos a operaçōes de empréstimo com prazo médio igual a três anos e } \\
\text { inferior a quatro anos. }\end{array}$ & $4,00 \%$ \\
\hline & $\begin{array}{l}\text { Ingressos de moeda estrangeira relativos a operações de empréstimo com prazo médio igual a } \\
\text { quatro anos e inferior a cinco anos. }\end{array}$ & $2,00 \%$ \\
\hline & $\begin{array}{l}\text { Ingressos de moeda estrangeira relativos a operaçōes de empréstimo com prazo médio igual a } \\
\text { cinco anos e inferior a seis anos. }\end{array}$ & $1,00 \%$ \\
\hline & $\begin{array}{l}\text { Operaçóes interbancárias realizadas entre instituiçôes financeiras no exterior e bancos } \\
\text { credenciados a operar em câmbio, no país. }\end{array}$ & $7,00 \%$ \\
\hline & Constituição de disponibilidades de curto prazo, de residentes no exterior. & $7,00 \%$ \\
\hline \multirow{5}{*}{ De $1^{\circ} .11 .96$ a 24.4 .97} & Ingressos de moeda estrangeira relativos a operaçōes de empréstimo com prazo médio inferior a três anos. & $3,00 \%$ \\
\hline & $\begin{array}{l}\text { Ingressos de moeda estrangeira relativos a operaçóes de empréstimo com prazo médio igual ou } \\
\text { superior a três anos e inferior a quatro anos. }\end{array}$ & $2,00 \%$ \\
\hline & $\begin{array}{l}\text { Ingressos de moeda estrangeira relativos a operaçōes de empréstimo com prazo médio igual ou } \\
\text { superior a quatro anos e inferior a cinco anos. }\end{array}$ & $1,00 \%$ \\
\hline & $\begin{array}{l}\text { Operaçôes interbancárias realizadas entre instituiçôes financeiras no exterior e bancos } \\
\text { credenciados a operar em câmbio, no país. }\end{array}$ & $7,00 \%$ \\
\hline & Constituição de disponibilidades de curto prazo no país, de residentes no exterior. & $7,00 \%$ \\
\hline \multirow{2}{*}{ De 25.4.97 a 16.3 .99} & $\begin{array}{l}\text { Operaçôes interbancárias realizadas entre instituiçôes financeiras no exterior e bancos } \\
\text { credenciados a operar em câmbio, no país. }\end{array}$ & $2,00 \%$ \\
\hline & Constituição de disponibilidades de curto prazo no país, de residentes no exterior. & $2,00 \%$ \\
\hline
\end{tabular}


(continua)

\begin{tabular}{|c|c|c|}
\hline Período & Operação & Alíquota \\
\hline \multirow{2}{*}{ De 17.3 .99 a 18.8 .99} & $\begin{array}{l}\text { Operaçóes interbancárias realizadas entre instituiçóes financeiras no exterior e bancos credenciados a ope- } \\
\text { rar em câmbio, no país. }\end{array}$ & $0,50 \%$ \\
\hline & Constituição de disponibilidades de curto prazo no país, de residentes no exterior. & $0,50 \%$ \\
\hline De 2.6.97 a 16.3 .99 & Transferência de recursos do exterior para aplicação em fundo de renda fixa. & $2,00 \%$ \\
\hline De 3.1 .00 a 3.1 .08 & Empréstimo em moeda estrangeira com prazo mínimo de até 90 dias. & $5,00 \%$ \\
\hline A partir de 3.1 .08 & Empréstimo em moeda estrangeira com prazo mínimo de até 90 dias. & $5,38 \%$ \\
\hline A partir de 4.1 .08 & Importaçôes e exportações de bens e serviços e demais operaçōes com câmbio. & $0,38 \%$ \\
\hline \multirow{2}{*}{ A partir de 17.3 .08} & $\begin{array}{l}\text { Operaçóes de câmbio para ingresso de recursos no país, inclusive por meio de operaçóes simultâneas, rea- } \\
\text { lizadas por investidor estrangeiro, para aplicaçáo no mercado financeiro e de capitais. }\end{array}$ & $1,50 \%$ \\
\hline & $\begin{array}{l}\text { Operação de compra de moeda estrangeira por instituição autorizada a operar no mercado de câmbio, } \\
\text { contratada simultaneamente com uma operação de venda. }\end{array}$ & $0,00 \%$ \\
\hline \multirow{3}{*}{$\begin{array}{r}\text { De } 22.10 .08 \text { a } \\
18.10 .09\end{array}$} & $\begin{array}{l}\text { Operaçóes de câmbio relativas a transferências do e para o exterior, inclusive por meio de operaçóes si- } \\
\text { multâneas, realizadas por investidor estrangeiro, para aplicação nos mercados financeiros e de capitais, na } \\
\text { forma regulamentada pelo Conselho Monetário Nacional. }\end{array}$ & $0,00 \%$ \\
\hline & $\begin{array}{l}\text { Operaçôes de câmbio para remessa de juros sobre o capital próprio e dividendos recebidos por investidor } \\
\text { estrangeiro. }\end{array}$ & $0,00 \%$ \\
\hline & $\begin{array}{l}\text { Operação de compra de moeda estrangeira por instituição autorizada a operar no mercado de câmbio, } \\
\text { contratada simultaneamente com uma operaçáo de venda; e operaçóes de câmbio de ingresso e saída de } \\
\text { recursos no e do país, referentes a recursos captados a partir de } 23 \text { de outubro de } 2008 \text { a título de emprés- } \\
\text { timos e financiamentos externos. }\end{array}$ & $0,00 \%$ \\
\hline A partir de 19.10. 09 & $\begin{array}{l}\text { Operaçôes de câmbio para ingresso de recursos no país, realizadas por investidor estrangeiro, para aplica- } \\
\text { çáo no mercado financeiro. }\end{array}$ & $2,00 \%$ \\
\hline A partir de 18.11 .09 & $\begin{array}{l}\text { Negociação em bolsa de valores localizada no Brasil, com o fim de lastrear emissão de depositary receipts } \\
\text { negociados no exterior. }\end{array}$ & $1,50 \%$ \\
\hline
\end{tabular}




\begin{tabular}{|c|c|c|}
\hline Período & Operação & Alíquota \\
\hline \multirow{3}{*}{ A partir de 5.10 .10} & $\begin{array}{l}\text { Nas liquidações de operações de câmbio contratadas por investidor estrangeiro, para ingresso de recursos } \\
\text { no país, inclusive por meio de operaçóes simultâneas, para aplicação no mercado financeiro. }\end{array}$ & $4,00 \%$ \\
\hline & $\begin{array}{l}\text { Nas liquidações de operaçóes de câmbio contratadas por investidor estrangeiro, relativas a transferências } \\
\text { do exterior de recursos para aplicação no país em renda variável realizada em bolsa de valores ou em bol- } \\
\text { sa de mercadorias e futuros, excetuadas operações com derivativos que resultem em rendimentos predeter- } \\
\text { minados; nas liquidaçóes de operaçóes de câmbio para ingresso de recursos para aquisição de ações, por } \\
\text { investidor estrangeiro, ou para a subscrição de açóes. }\end{array}$ & $2,00 \%$ \\
\hline & $\begin{array}{l}\text { Nas liquidaçóes de operaçóes de câmbio para fins de retorno de recursos aplicados por investidor estran- } \\
\text { geiro no mercado financeiro. }\end{array}$ & $\mathbf{0 , 0 0} \%$ \\
\hline \multirow{4}{*}{ A partir de 30.12 .10} & Operaçóes de câmbio contratadas por investidor estrangeiro em bolsas de valores, de mercadorias e futuros. & $6,00 \%$ \\
\hline & $\begin{array}{l}\text { Liquidação de operaçóes de câmbio contratadas por investidor estrangeiro para aplicaçáo no mercado fi- } \\
\text { nanceiro e de capitais. }\end{array}$ & $6,00 \%$ \\
\hline & $\begin{array}{l}\text { Aplicação por estrangeiros em renda variável na Bolsa de Valores ou na Bolsa de Mercadorias e Futuros, } \\
\text { na forma regulamentada pelo CMN, excetuadas operaçóes com derivativos. }\end{array}$ & $2,00 \%$ \\
\hline & $\begin{array}{l}\text { A partir de 1\%/1/11: aquisição de cotas de fundos de investimento em participaçóes, de fundos de investi- } \\
\text { mento em empresas emergentes e em cotas dos referidos fundos; liquidaçóes de operaçóes simultâneas de } \\
\text { câmbio para entrada de recursos via cancelamento de depositary receipts; mudança de regime do investidor } \\
\text { estrangeiro de investimento direto para investimento em açóes negociáveis em bolsa. }\end{array}$ & $2,00 \%$ \\
\hline A partir de 29.3 .11 & $\begin{array}{l}\text { Nas liquidaçóes de operaçóes de câmbio contratadas a partir de } 29 \text { de março de } 2011 \text {, para ingresso de re- } \\
\text { cursos no país, inclusive por meio de operaçóes simultâneas, referente a empréstimo externo, sujeito a re- } \\
\text { gistro no Banco Central do Brasil, contratado de forma direta ou mediante emissáo de títulos no mercado } \\
\text { internacional com prazo médio mínimo de até } 360 \text { dias. }\end{array}$ & $6,00 \%$ \\
\hline A partir de 6.4 .11 & $\begin{array}{l}\text { Nas liquidações de operaçóes de câmbio contratadas a partir de } 7 \text { de abril de } 2011 \text {, para ingresso de recur- } \\
\text { sos no país, inclusive por meio de operaçóes simultâneas, referente a empréstimo externo, sujeito a registro no } \\
\text { Banco Central do Brasil, contratado de forma direta ou mediante emissáo de títulos no mercado internacio- } \\
\text { nal com prazo médio mínimo de até } 720 \text { dias. }\end{array}$ & $6,00 \%$ \\
\hline A partir de $1^{\circ} .12 .11$ & $\begin{array}{l}\text { Nas liquidações de operaçóes de câmbio contratadas a partir de } 1 \% / 12 / 11 \text {, para aplicação no país em renda } \\
\text { variável realizada na Bolsa de Valores ou na BM\&F, excetuadas operaçóes com derivativos; para aquisição } \\
\text { de açóes, de cotas de fundos de investimento ou para fins de retorno de recursos aplicados por investidor } \\
\text { estrangeiro nos mercados financeiro e de capitais }\end{array}$ & $\mathbf{0 , 0 0 \%}$ \\
\hline
\end{tabular}

Fonte: Receita Federal do Brasil e Caixa Econômica Federal. 


\section{Anexo B}

\section{Tabela I - Estatísticas descritivas}

\begin{tabular}{|c|c|c|c|c|c|c|c|}
\hline & DCAMBIO & DEMBI & DIOF & DRESERVAS & DSELIC & IECA & IECRF \\
\hline Mean & 0.004677 & -4.177723 & 1.886245 & 1553.441 & -0.012426 & 728.6292 & 597.4421 \\
\hline Median & 0.005300 & -9.434524 & -0.002475 & 883.0000 & -0.030000 & 356.9000 & 524.1500 \\
\hline Maximum & 0.463900 & 421.0227 & 446.0000 & 14589.00 & 1.370000 & 14536.20 & 7214.000 \\
\hline Minimum & -0.328200 & -342.2871 & -305.0000 & -21522.00 & -0.980000 & -6065.200 & -5246.200 \\
\hline Std. Dev. & 0.093869 & 99.53846 & 60.23185 & 4416.985 & 0.227333 & 1984.189 & 1812.197 \\
\hline Skewness & 1.224655 & 1.070203 & 2.439343 & -0.375979 & 1.848591 & 3.696888 & -0.084907 \\
\hline Kurtosis & 8.838777 & 8.469992 & 26.99888 & 6.863303 & 14.97679 & 25.93841 & 4.568921 \\
\hline Jarque-Bera & 337.4278 & 290.3930 & 5047.879 & 130.3788 & 1322.366 & 4888.725 & 20.96045 \\
\hline Probability & 0.000000 & 0.000000 & 0.000000 & 0.000000 & 0.000000 & 0.000000 & 0.000028 \\
\hline Sum & 0.944700 & -843.9000 & 381.0215 & 313795.0 & -2.510000 & 147183.1 & 120683.3 \\
\hline Sum Sq. Dev. & 1.771080 & 1991489. & 729203.0 & $3.92 \mathrm{E}+09$ & 10.38771 & $7.91 \mathrm{E}+08$ & $6.60 \mathrm{E}+08$ \\
\hline Observations & 202 & 202. & 202. & 202. & 202. & 202. & 202 \\
\hline
\end{tabular}

Fonte: Saída do Eviews. 